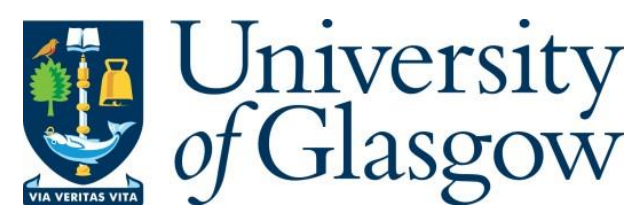

Gherghina, S. and Plopeanu, A. (2020) Who wishes to return? Ties to home country among the Romanian migrants. Nationalities Papers, (doi: 10.1017/nps.2019.72).

There may be differences between this version and the published version. You are advised to consult the publisher's version if you wish to cite from it.

http://eprints.gla.ac.uk/214147/

Deposited on: 20 April 2020

Enlighten - Research publications by members of the University of Glasgow http://eprints.gla.ac.uk 


\title{
Who Wishes to Return? Ties to Home Country among the Romanian Migrants
}

\author{
Sergiu Gherghina \\ Department of Politics \\ University of Glasgow \\ Aurelian Plopeanu \\ Department of Interdisciplinary Research - Humanities and Social Sciences \\ Al. I Cuza University lasi
}

\begin{abstract}
The research focusing on return migration from the perspective of migrants' relationship with the country of origin has emphasized the emotional and economic ties. Quite often, these ties have been examined separately and there is little indication of what counts more. This article addresses this gap in the literature and analyzes the extent to which the sense of belonging, media consumption, networks of friends and regular visits in the country of origin could have an effect on the intention to return. It controls for remittances, voting in the elections of their home country and age. The empirical analysis uses an original dataset including individual level data. This was collected through an online survey in January 2018 on a sample of 1,839 first generation migrants from Romania.
\end{abstract}

Keywords: migrants, return, emotional attachment, regular visits

\section{Introduction}

Migrants return to their country of origin for different reasons. Earlier research went in two directions in the attempt to provide explanations for this decision: the integration in the country of residence and the ties with the country of origin. The latter approach relies to some extent on emotional elements that involve an idyllic image of their home country, marked by stories, experiences and memories (Tsuda 2003; Wessendorf 2007; Datta 2012). In particular, earlier research showed the importance of migrants' nostalgia for their places of birth or childhood, strong emotional connection with their family or relatives, social networks with friends or acquaintances (Vlase 2013; Efstratios et al. 2014; Kraler et al. 2014; Erdal \& Ezzati 2015; Nedelcu \& Wyss 2016). At the same time, the ties with the country of origin may rely on economic elements such as occasional visits, send pecuniary savings and "ideational remittances" to their homeland (Fargues 2011; Vlase \& Voicu 2018). These resources may have a positive effect on communities in the homeland (Zhao 2002; Waddell \& Fontenla 2015; Barbiano di Belgiojoso 2016) and create a more appropriate setting for return. 
All these indicate that the migrants' decision to return have a complex web of reasons. That may be one reason for which explanations have not reached scientific unanimity (Constant \& Massey 2002; de Haas \& Fokkema 2011). As such, there are two under-explored issues in the literature that approaches return migration from the perspective of migrants' relationship with the country of origin. First, the literature lacks an integrative approach that combines the individual and contextual drivers for return migration (de Haas et al. 2015). Second, the determinants have been often identified in isolation and rarely subjected to an empirical test against each other to see which one weighs more.

Our article addresses these two gaps in the literature and aims to analyze what several factors related to the migrants' country of origin influence their intention to return. We argue and test how sense of belonging, media consumption, networks of friends and regular visits in the country of origin may have an effect. We control for remittances, political participation in the home country and age. Earlier studies explained that intentions to return and real actions may be different (de Haas 2009), with empirical evidence illustrating that the decision to return is not always accompanied by an actual desire to proceed that way (de Bree et al. 2010). However, a large body of literature indicates that intentions shape the decision to return (Zaiceva \& Zimmermann 2008; Carling \& Pettersen 2014; Vlase \& Voicu 2018). Intentions influence and help understanding the actual behavior of individuals (Barbiano di Belgiojoso 2016) and thus intentions and real decisions to return are influenced by the same factors (Waldorf 1995). This article follows the latter approach and considers intentions to return as relevant proxies for the actual decision. As a result, some theoretical arguments provided in the following pages are partially inspired from studies focusing on the action than on the intention per se.

The empirical analysis uses an original dataset including individual level data. This was collected through an online survey in January 2018 on a convenience sample of 1,839 first generation migrants from Romania. The Romanian migrants were selected as subject of this study due to their high mobility across a large number of countries in the world. According to recent estimates, one in six Romanians lives abroad (UN Report 2017), thus making the fourth largest diaspora in Europe. Our empirical tests rely on both bivariate (correlation) and multivariate (ordinal logistic regression) analyses. 
The remainder of this article proceeds as follows. The first section reviews the literature on return migration and formulates four testable hypotheses corresponding to different components of the relationship between migrants and their country of origin. Next, we briefly describe the case selection, variable measurement and methodology. The third section provides an overview of Romanian migration (including return) over the last two decades. The fourth section includes the empirical findings, while the article concludes with the major implications and avenues for further research.

\section{Belonging, Connections and Physical Presence}

The literature on return migration highlights three major determinants relative to their country of origin: a sense of belonging, the connection that migrants have with the ones left behind and the time spent by them in their country of origin. This theoretical section is structured along these three lines of enquiry and explores the ways in which they could play a relevant role in the intention to return.

The first potential determinant is the sense of belonging that migrants have to their country of origin. Several concepts have been used to capture this sense of belonging, ranging from attachment or identity to pride. This article uses the latter path and argues that national pride, relative to their country of origin, is likely to be an important cause for their intention to return. Emotional attachment encapsulates a series of feelings related to belonging. Some studies considered that national pride is for migrants a proxy for effective attachment to their country of origin (Smith \& Kim 2006). The attachment to the "homeland" is important both for personal and collective identities (Easthope 2009, p.72). National and ethnic identities give the sense of belonging for individuals and groups, generated by the feelings of "exhilaration", which may be translated into deeper sentiments of national pride (Kakar 1996). The national pride is an emotional and affective concept in relation to the "love of nation" (Ha \& Jang 2015, p.55). There are two types of national pride: one positively aimed to the nation's economic, political, social, institutional achievements (patriotism) and another based on nationalism that offers a superior perspective over other nations or communities based on particular historical, cultural or traditional background (Schatz et al. 1999; de Figueiredo \& Elkins 2003). Migrants who are emotionally attached to "homeland" are more inclined to return. This approach is in line with previous findings 
according to which such decisions are formed by cultural and historical background features (Cassarino 2004).

The sense of belonging is not developed only through strong feelings as national pride. An alternative way to maintain it is by staying connected to the social, political, cultural and economic realities in the country of origin. The bonds are strengthened through the consumption of media from the country of origin. Those who watch this type of media have an interest towards what happens in the homeland and are more likely to display intentions of return. In the case of Turkish second-generation immigrants in several European countries, Fokkema (2011) found that watching TV stations from Turkey positively influence their intention to return to their parents' country of origin. In the case of older Italian and Spanish migrants from Switzerland, their intentions to return in the country of origin is higher among those who watch TV programs only in the mother tongue in comparison with those who consume media in foreign languages (Bolzman et al. 2006).

The strong ties with the people from the country of origin can be another important predictor for the intention to return (de Haas et al. 2015). This happens due to the emotional connection with a familiar place in the country of origin, where parents, relatives and close friends reside (Ritchey 1976). Research has shown that the social attachments to the country of origin can positively predict return migration due to "a desire to remain a member of the 'home' community by maintaining relationships with family members or friends" (Duval 2004, p.62). Another mechanism through which the relationship with friends and relatives could influence the intention to return is the role these play in the easiness to reintegrate in the home societies, upon return (Labrianidis \& Kazazi 2006; Vlase \& Voicu 2018). In a hierarchy of reasons influencing the migrants to return, the relationship with friends and relatives is the second as importance; through these connections, the migrants were encouraged to take that decision (Hatziprokopiou \& Labrianidis 2005).

The importance of this cause can be observed for several groups of migrants across the world. For example, the reasons behind return migration in Ireland consisted of the desire to be close to relatives and friends (McGrath 1991). The Lebanese return migrants chose this path due to family and friends who were living in Lebanon (Stamm 2006), while the Caribbean young migrants could take into consideration the return in their countries of origin based on the network connections with the native land (Reynolds 2010). In Norway, those immigrants who are less integrated and keep transnational ties with the country of 
origin are more likely to return home (Carling \& Pettersen 2014). A study dedicated to the Romanian migrants in Switzerland reveals how connections with their families in the country of origin are developed through ICT-mediated communication. These means transform the feeling of togetherness and help with the creation of new practices of "being together" (Nedelcu \& Wyss 2016). In this way, the ties are better maintained and the physical distance downplayed.

In addition to the network of friends, the regular visits are another way to keep in touch with the country of origin. Research on the Southern Italian migrants in Switzerland shows that the regular visits had a dual function: to maintain contact with those they knew and to invest in their native community. The Italian migrants visited their community of origin at least once together with their children, often as a preamble for their future decision to return for good (Wessendorf 2007). As such, regular visits to the country of origin are also intended to reassure the migrants that a permanent return will be the appropriate decision. Empirical evidence shows that for some groups they are part of a common cultural and traditional routine before reaching a decision. For example, the regular visits of French migrants from Guadeloupe and Martinique were an important element to factor in when deciding to return (Condon \& Ogden 1996), while such visits were the decisive actions for the return of Ghanaian migrants (Fehler 2011). Similarly, in the case of British migrants returning from Spain, the regular visits to Great Britain appeared to be relevant predictors for their future return (Giner-Monfort et al. 2016). ${ }^{1}$

Following these arguments, we expect that:

$\mathrm{H} 1$ : Emotional attachment to the country origin increases the likelihood to return.

$\mathrm{H} 2$ : The consumption of media from the country of origin increases the likelihood to return.

H3: Strong relations with friends in the country of origin increase the likelihood to return.

$\mathrm{H} 4$ : More visits to the country of origin increase the likelihood to return.

\section{Control variables}

In addition to these main effects, our analysis will include three control variables that could determine the intention to return. These variables reflect different types of activities or

\footnotetext{
${ }^{1}$ One could argue for reverse causality in which regular visits to the country of origin are driven by the desire to return. While we cannot entirely exclude this possibility, we believe that those who intend to return are less likely to invest resources in regular visits. For them, such visits will bring minimal gains and they could be more inclined to save the resources for a later stage, after their return.
} 
features, which are not theoretically linked. As we will see from the empirical analysis, they are not empirically related either, which is a plus for the multivariate regression analysis. Based on the findings of earlier studies, we control for an economic variable (remittances), a political participation variable (voting in national elections of the home country) and for a socio-demographic variable (age). ${ }^{2}$ Remittances are important for return migration decisions (Dustmann \& Mestres 2010) because they are usually driven by a rational strategy according to which migrants send money home to make sure that the necessary financial resources are covered prior to their return (Fokkema 2011; Bonifazi \& Paparusso 2018; Collier et al. 2018). Owusu (1998) found that the remittances sent by Ghanaian migrants for house-building projects were important signals for their intention to return in their country of origin. At the same time, remittances are crucial to retain migrants' family ties and social visibility (Duval 2004). Labrianidis and Kazazi (2006) found that, in the case of returnees, their decision was premeditated through constant remittances for building-houses process or initiating start-up businesses. However, the relationship between remittances and intention to return is not always straightforward. For example, the ongoing estate investments were a reason for many Ghanaian migrants to postpone their return (Peil 1995). The remittances can be isolated from the intention to return when the action of sending money is driven by the willingness to cover the financial needs of those who remained at home (Marcu 2018). Migrants will continue to send money as long as they perceive that this could be of use for their families and relatives. In particular cases, the remittances could be used to ensure the transition towards migration, e.g. migrants leave children behind, send money to complete their education and then take them abroad. As such, remittances can be linked with return migration intentions and indirect channel for communication with the families left at home (Sandu 2016).

Voting in the national election of their country of origin is a proxy for maintaining ties with the homeland. This has a partial equivalent in the resistance theory, which claims that migrants are unlikely to change their behavior in contact with institutions from the country of residence, following the values internalized during their life in their country of origin. Voting in elections shows an interest towards what happens in the country of origin and

\footnotetext{
${ }^{2}$ We controlled for a series of other variables that were mentioned as potential drivers for return by previous research, e.g. job status, medium of residence, country of residence, gender or education. These variables did not provide empirical evidence and thus, for reasons of parsimony, were not reported in the findings.
} 
allows the migrants to stay close to the political realities of the homeland. Migrants with this approach could be more keen about return in comparison with those who ignore the elections. The reason for which we treat this as a control variable rather than as main effect is that the relationship is not straightforward. There are also situations in which migrants vote in national elections without the intention to return, driven either by their general participatory behavior (i.e. elections as a civic duty and constantly vote in all types of elections) or cast a vote thinking about the relatives and friends at home (Gherghina \& Tseng 2016).

Age could also play a relevant role in the intention to return. Paparusso and Ambrosetti (2017) point out that those migrants who left their country of origin at younger ages, being highly integrated in the host societies compared with the older ones, due to educational, cultural and socio-economic accumulation, are more likely to stay in the country of residence.

\section{Research Design}

To empirically test these effects, we use individual level data from an original web survey conducted among Romanian migrants in January 2018. The Romanian migrants were selected as subject of this study due to their high mobility across a large number of countries in the world. According to the UN estimates, in 2017 there were 3.6 million Romanians living abroad (UN Report 2017), thus making the fourth largest diaspora in Europe after the UK, Poland and Germany - all countries with much larger population. The Eurostat data and 2011 census at national level indicate that there are approximately 20 million Romanians living in the country. As such, the percentage of migrants relative to the population residing in the homeland is quite high. The preferred migration destinations are Italy, Spain, UK, Germany, France and the United States (Anghel 2013). This is reflected also in our sample of respondents where almost $70 \%$ of those who filled in the online survey live in one of these six countries. The remaining $30 \%$ live in other 38 countries around the world as far as Australia, Japan, New Zealand, Singapore or Tonga.

In the absence of official reliable statistics regarding the Romanian migrants, we cannot know the features of the entire population and thus we could not use probability representative sampling. In addition, we aimed to include also the irregular migrants. We used a convenience sample in which the respondents were neither pre-selected nor part of a 
pool of available individuals. Although research on a convenience sample has a series of disadvantages - among which the confinement of the findings to the respondents and the difficulty to have generalizable results - this remains an important tool to collect valuable data. This paper aimed to analyze broader patterns in the migrant population and for these reasons a survey is preferred to interviews. The survey results are informative and have important implications for further research on return migration because, among others, it identifies items on which in-depth qualitative research can be carried out. The survey used here can be seen as a first attempt to capture the attitudes and opinions of Romanian migrants at a large scale, comparable with surveys conducted for other groups of East European migrants in previous studies. Due to this broad perspective, the survey did not focus on particular countries. The main purpose of the data collection was to gauge the opinions of Romanian migrants worldwide. Particular analyses, relative to their country of residence can be ran with the individual level data presented here especially that for some countries we have several hundreds of respondents.

We distributed the online survey mostly through messages on Facebook groups or discussion forums of Romanians living abroad, and by e-mails sent to representatives of Romanian associations and organizations. The dataset includes 1,839 answers collected from first generation migrants of Romanian origin. Although the survey had no explicit age limit, all respondents were between 19 and 71 years old, with no bias in terms of age and education. $^{3}$ In general, there is great variation in the respondents' profile due to the different patterns of migration to these countries. The profile varies across the independent and control variables of this study and in terms of other sociodemographic variables (e.g. gender, occupation, area of origin and of residence).

The dependent variable is measured on an 11-point ordinal scale as the answer to the following question: "How likely is it for you to return to live in Romania in the following two years?". The respondents were asked to choose between different values on a scale ranging between 0 (very low likelihood) and 10 (very high likelihood). ${ }^{4}$ Emotional attachment

\footnotetext{
${ }^{3}$ Some online surveys are biased towards the young or old respondents due to their skills in using technology or time they can allocate, but this was not the case here.

${ }^{4}$ Following the suggestion of one reviewer for this journal, we conducted a sensitivity analysis aimed at identifying how stable are the results to minor modifications in the methodology for data analysis. We recoded the dependent variable into a dummy variable (low vs high likelihood of return) and compared it with the results of ordinal logistic regression presented in this article. The results were very similar and we opted for the ordinal regression due to the higher accuracy in measuring the intention to return.
} 
with the country or origin $(\mathrm{H} 1)$ is measured on a five-point ordinal scale based on the following question: "How emotionally attached do you feel to Romania?". The possible answers range between "not at all" (coded 1 ) and "very much" (coded 5). The consumption of media from the country of origin is a cumulative index that includes the use of TV and newspapers from Romania (online as well). The questions about media use was the following: "How often do you read, on average, the Romanian newspapers (including the online version) / watch, on average, Romanian TV stations (including online)?". The available answers ranged between "never" (coded 1) and "daily or almost daily" (coded 6) for each of the two items. The composite index takes values on an 11-point ordinal scale between 2 (never reading newspapers or watching TV) to 12 (using both types of media daily or almost daily).

The relations with friends from the country of origin $(\mathrm{H} 3)$ is measured through the answers provided to the following question "How often do you keep in touch with your friends in Romania (relatives are excluded)?". The answers are coded on a five-point ordinal scale that ranges between "not at all" (1) and "very often" (5). The country was chosen as point of reference to be consistent with what captured by the other questions; we also asked respondents about attachment to the region and locality in which they lived and both correlate highly to country attachment. The visits to the country of origin $(\mathrm{H} 4)$ is operationalized also on a five-point ordinal scale based on the questions "How often have you visited Romania in the last year?". The possible answers are "never" (1), "one-two times" (2), "three-four times" (3), "five-six times" (4) and "more than six times" (5).

Turning to controls, the remittances variable is measured through the answers to the following question "Have you sent money to Romania (including what you carried with you on an eventual visit) in the last 12 months?". This is a dichotomous variable coded 0 for the No answers and 1 for Yes. ${ }^{5}$ All respondents who answered this question were filtered by a previous question asking whether they have sent money home in the last year. Voting in national elections was measured as the answer to the following question "During your stay in the current country of residence, how often have you voted in the national elections in Romania?". The available answers were recorded on an ordinal scale ranging from "never"

\footnotetext{
5 The questionnaire included a follow-up question for those who anwered positively about sending remittances, which asked how often they did so. The correlation between that variable and intention to return is very weak and we also lose cases (all those respondents who did not send remittances).
} 
(1) to "every time I had the opportunity" (5). The latter refers to the fact that migrants have different experience of migration and age, and become voters at various moments in time. In the cognitive pre-testing of this survey, it became clear that respondents were aware of the meaning of that answer option and did not refer to something else (e.g. when they were located close to the voting station). Age is measured though the year of birth and it is an interval-ratio variable. For all the variables, the "DK/NA" answers are treated as missing values and excluded from the analysis. The summary statistics for all variables included in the analysis is available in Appendix 1.

\section{Overview of the Romanian Migration and Return}

Before running the empirical analysis, it is relevant to have a general view of Romanian migration and return. After the fall of communism, many Romanians had the chance to leave the country to study or work abroad, especially in West European countries. After restricted or irregular migration flows during the 1990s and beginning of 2000s, the EU accession in 2007 was, definitely, a turning point regarding the immigration management through a large freedom for human capital mobility. The main pulling factor for the Romanian migrants in Spain or Italy was represented by the networks of migration (Anghel 2008; Elrick \& Ciobanu 2009), solidarities based especially on kinship and friendship. Other triggers of migration were the wage differentials, the desire for personal value recognition, better job prospects including opportunities to be promoted into their careers, and negative attitudes towards the political class that negatively affects the country's future through corruption.

According to the UN estimates (2017), from a total of 3.6 million Romanians living abroad, around 2.7 million are of working age, equivalent to more than $20 \%$ of Romania's working age population. The Friedrich Ebert Foundation's Social Monitor (2018) claims that $20 \%$ of the Romanians with age between 25 and 40 live and work outside their country of origin. Almost one quarter (23\%) of the highly educated Romanians leave their country for better standard of living in G20 countries (OECD 2017, p.11). All these patterns of migration are likely to have a negative impact on the demography, family structure, financing education, pensions and healthcare system. In many areas there is a shortage of specialists in the healthcare system caused by the exodus of doctors abroad between 2000 and 2013; only in 2013 the number of doctors leaving the country exceeded 14.000, which is more than a quarter of all the doctors in the country (De Rosa et al. 2018). 
In 2017, the overall number of Romanian migration outflow was around 220,000 individuals (Popa 2018), contributing to a general high level of outward migration. The return migration remained overall limited (Atoyan et al. 2016, p.14) with levels extremely low a decade ago. In 2006-2008, the return migration percent in the total number of legal workforce was 7.65\%, significantly higher among men, 11.09\% (Martin \& Radu 2012, p.111). A high return migration was expected during the financial crisis due to the shortage of jobs in many countries of residence. However, instead of return most Romanian migrants decided to re-migrate in West European countries that were less affected by the financial crisis. In 2009 and 2010, approximately 26\% of the Romanian households had at least one family member that migrated; only $4.5 \%$ of the households had at least one returning migrant (Stănculescu \& Stoiciu 2012). Another study found that the return migration intentions of the Romanian health professionals was low, only $24 \%$ of those who were interviewed taking this possibility into consideration (Roman \& Goschin 2014, p.114).

Quite often, those with poor education and with difficulties in finding a job are those who return the most (Zaiceva \& Zimmermann 2012, pp.9-10). Stănculescu and Stoiciu (2012) found that the Romanian migrants who worked in agriculture were more inclined to return than the ones employed in other sectors of activity, while the same pattern was validated in the case of those coming from Italy and Spain (Eurofound 2012). A study on a sample of randomly selected Romanian adult migrants from the region of Madrid shows that those who want to return are less integrated into the host society, having difficulties to use the Spanish language, to cultivate social relationships with the locals, to be legally employed on the national labor market (Sandu et al. 2009, pp. 62-66). Also, these migrants take into consideration starting a business, investing remittances to buy goods, build houses and repay their debts in Romania. They would prefer to return in the context of highly paid jobs and if they are accompanied back home by another family member.

\section{The Effect of Attachment and Regular Visits}

This section starts with a general discussion about the distribution of preferences for return. It is followed by inferential statistics that includes bivariate and multivariate relationships. The latter takes the form of ordered logistic regression, because the dependent variable is an ordinal measure. Before running the regression, we tested for multicollinearity and the results indicate no highly correlated predictors, i.e. the highest value is 0.29 . The 
interpretation of empirical results focuses more on the size of the effect / relationship rather than on the statistical significance - although we report it - because we do not seek to make generalizable claims based on our convenience sample.

Figure 1 includes a quantile plot that depicts on the vertical axis the willingness to return to the country of origin and on the horizontal axis the fraction of the data. The distribution indicates that a large share of the respondents is not willing to return to their home country in the near future, with roughly half of the migrants choosing the very low likelihood end of the scale. In spite of this preponderance, there is considerable variation in the willingness to return. For example, the medium likelihood to return is the third popular option, while the very high likelihood to return exceeds several other choices. ${ }^{6}$

Figure 1: The Distribution of Respondents according to the Willingness to Return
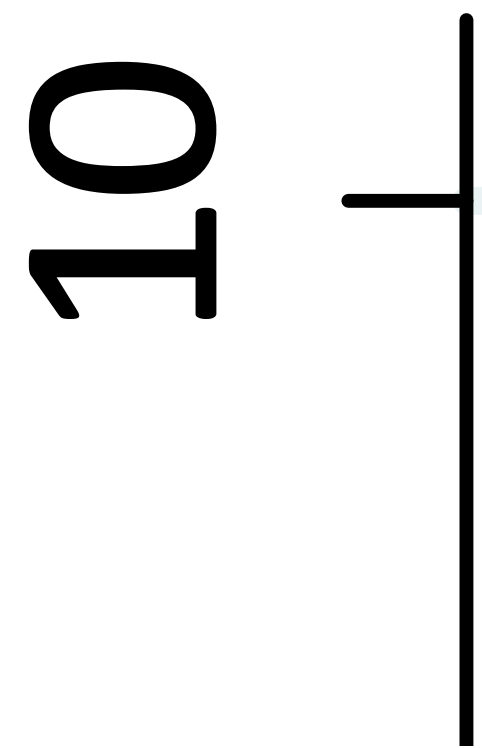

The limited willingness of the respondents to return can be explained through several developments. A study conducted in 2017 by Repatriot and Open-I Research on almost 1,200 Romanian migrants found that their unwillingness to return in Romania is mostly influenced by the following barriers: corruption, poor health system, bureaucracy and the political

\footnotetext{
${ }^{6}$ There is only a low possibility to have these two categories as biased choices due to the scale used. Earlier research showed that people who are undecided often choose the middle option. We used a dynamic scaler in the online survey which did not record the values when people do not move it. Thus, even for a middle value they have to make efforts and position the slider in that point.
} 
climate (Repatriot 2017). Since these issues are thorough and require very long time to change, the likelihood of return can hardly increase in a short time span. Other factors that may negatively influence the decision of the Romanian migrants from Spain to return were: better standards of living abroad, difficulties to adapt home and restart a new life, problems regarding the uprooting of their children already adapted to a specific lifestyle or even marriage with local people (Șuiu 2015, p.76).

The results of the bivariate relationships - non-parametric correlations due to the ordinal scale of most variables - are included in Table 1. The direction, size of the coefficients and statistical significance at the 0.01 level provide empirical support for all hypothesized relationships. The results indicate that emotional attachment to the home country, the use of media from Romania, connection with friends in the homeland and regular visits to Romania are associated with a higher intention to return. The value of the coefficients indicates the possibility to rank them according to the strength of the association. This almost matches entirely the order of the hypotheses, with the latter two variables swapping seats, i.e. regular visits to Romania correlates higher with the intention to return than the connections with friends.

Table 1: Correlation Coefficients

\begin{tabular}{lcc}
\hline & Correlation coefficient & $\mathbf{N}$ \\
\cline { 2 - 3 } Emotional attachment & $0.31^{* *}$ & 1741 \\
Media consumption & $0.23^{* *}$ & 1747 \\
Connection with friends in homeland & $0.17^{* *}$ & 1762 \\
Regular visits to Romania & $0.21^{* *}$ & 1761 \\
\hline Remittances & $0.11^{* *}$ & 1765 \\
Voting in national elections & $0.09^{* *}$ & 1765 \\
Age & $0.14^{* *}$ & 1715 \\
\hline
\end{tabular}

Notes: The correlation coefficients are non-parametric (Spearman).

$* * p<0.01 ; * p<0.05$

The correlations between the controls and the dependent variable are positive and statistically significant at the 0.01 level. They all correlate lower than the main effects. The results show that respondents who send remittances, who vote in national elections and who are younger (the measurement is year of both and that is why the sign is positive) are 
more inclined to return. Among these, age correlates the highest with the intention to return, while political participation the least. This is not surprising since voting refers to a particular type of interest in what happens in the home country and not many respondents display it (i.e. more than half have never voted or voted only once).

The results of the regression analysis (Table 2) bring important nuances to what observed in the correlation. The interpretation of results is relative to the group of migrants who have very high intentions to return, i.e. the reference category. Model 1 includes all four predictors from the hypothesized relationships and confirms to a great extent the results of the correlations. There is empirical support for all the main effects, which are statistically significant at the 0.01 level. The Romanian respondents who are emotionally attached to their country of origin $(\mathrm{H} 1)$ are 1.61 times more likely to return compared to those with less attachment. The emotional attachment is the strongest predictor among the hypothesized effects. Those migrants who make more regular visits to Romania are 1.38 times more likely to return compared to the others. The other two variables - connection with friends in homeland $(\mathrm{H} 3)$ and media consumption $(\mathrm{H} 2)$ - have a weaker effect.

Since emotions characterize the current migration phenomenon worldwide (Gray 2008), the attachment of the Romanian migrants to their country of origin could be a motivation for future return migration intentions, especially when facing difficulties and obstacles in the foreign societies (Marcu 2012, p.12). This attachment could be stimulated by several subjective emotional triggers: homesickness, loneliness, uncertainty, discrimination or difficulties to be assimilated or integrated in the host societies or to fully embrace the process of acculturation abroad. Moreover, periodic family visits and holidays in Romania may strength and increase the emotional attachment with the native places, since this attachment is based on a sense of "nostalgia" (Rubenstein 2001). These effects do not vary across the countries of residence. We included the countries in various model specifications but without an effect we left them out of the analysis for reasons of parsimony. When including the six most important countries of residence into the model as a nominal variable according to the number of Romanian respondents (and migrants in general), there is no effect on the likelihood to return. ${ }^{7}$ When reporting the results of logistic regression by the

\footnotetext{
${ }^{7}$ The number of respondents in these countries is (percentage of the total number of respondents in bracjets): 465 in Great Britain (25\%), 308 in Germany (17\%), 159 in Italy (9\%), 156 in France (9\%), 103 in Spain (6\%) and 99 in the US (6\%).
} 
country of residence, the effects are very similar both in terms of size and statistical significance. Also, we have controlled for a clustering effect of living in the same country of destination by running regression models with and without robust standard errors. The significance levels and effect size of regression coefficients in the two models (with and without robust standard errors) is very similar.

Model 2, which includes the controls, does not bring much additional information. The main effects $(\mathrm{H} 1-\mathrm{H} 4)$ are statistically significant, with comparable values of the coefficients to Model 1 . Two controls have very weak effect on the intention to return: voting in national elections and age. The latter is statistically significant, but with a very weak effect, making almost no difference if the migrants are young or old when including other motivations in the same regression analysis. This observation is particularly relevant because the Romanian migration in the last 15 years includes population of different age. Since there are no migrants from certain age segments more willing to return to the country compared to the others, the initial diversity that characterizes the decision to leave the country is reflected also in the decision to return. The importance of other motivations in the decision to return (i.e. age has almost no effect in the regression analysis although it correlates positively in the bivariate analysis) appears to be essential.

The poor effect of voting in national elections is counter-intuitive because usually migrants participate in the politics of their home country when they have an interest to continue their life there. Two competing explanations can clarify why there is no effect. On the one hand, those who vote are willing to return to the country, but their numbers are matched by those who are also willing to return but do not care about political involvement (and thus do not vote). On the other hand, the Romanian migrants voting in Romanian legislative elections do it out of a sense of duty and for those who live in the country - and with whom they maintain contact.

Sending remittances has a relevant effect on the intention to return: migrants who send money to Romania are 1.18 times more likely to return compared to those who do not send money. The macroeconomic implication of remittances for Romania has been already documented (Blouchoutzi \& Nikas 2010; Ban 2012) but the microeconomic perspective is equally important. Romanian migrants send money home not only to support their families but also to serve them, in a way preparing the field for their return. Our survey had a battery of questions - not reported in this article - that asked the Romanian migrants if they have 
properties and savings in Romania and a great deal of them answered positively. When matching those answers with the remittances sent we could observe that quite a few migrants send remittances for their own use at a later stage. As such, the positive effect of remittances on the desire to return is not surprising.

Table 2: Ordered Logistic Regression

\begin{tabular}{lcc}
\hline & Model 1 & Model 2 \\
\cline { 2 - 3 } Emotional attachment & $1.61^{* *}(0.08)$ & $1.64^{* *}(0.08)$ \\
Media consumption & $1.09^{* *}(0.16)$ & $1.08^{* *}(0.16)$ \\
Connection with friends in homeland & $1.14^{* *}(0.06)$ & $1.12^{*}(0.06)$ \\
Regular visits to Romania & $1.38^{* *}(0.07)$ & $1.33^{* *}(0.07)$ \\
\hline Remittances & & $1.18(0.12)$ \\
Voting in national elections & & $1.02(0.03)$ \\
Age & & $1.03^{* *}(0.01)$ \\
\hline $\mathrm{N}$ & 1718 & 1670 \\
Pseudo $\mathrm{R}^{2}$ & 0.05 & 0.05 \\
Log likelihood & -2983.31 & -2872.06 \\
\hline
\end{tabular}

Notes: The reported coefficients are odds-ratios (standard errors in parentheses) $* * p<0.01 ; * p<0.05$

These empirical results allow the formulation of two general conclusions. First, the relationship of Romanian migrants with their home country has an influence on the intention to return in different ways. The four variables tested in this article reflect the emotional attachment, information seeking habits, political interest and physical presence in the country of origin. All four have an effect which is stronger or more robust than other controls included in the statistical model. Thus, these effects do not get weaker when introducing new variables in the regression model. Second, there is a difference in the explanatory power of these variables. The intention to return to the home country is driven by variables that reflect attitudes (emotions) and behavior (physical presence). Figure 2 includes the graphical representation of the strongest effects highlighted in the regression analysis: emotional attachment to Romania and regular visits. Both have a positive effect on the intention to return. The size of the effect is stronger for emotional attachment. These findings indicate that the intention to return among the surveyed Romanian migrants has a 
complex underlying reasoning, which is oriented at broader issues. Narrower elements such as following what happens in the country or ties with the friends left behind have a weaker impact. One possible explanation for this is that migrants can find substitutes in the country of residence for the more specific issues. This can be a valid explanation especially for the Romanian migrants with a longer stay in their countries of residence. The survey included countries that are the preferred destinations of Romanian migrants and more than two thirds of the respondents reside in them. A behavior such as the regular visits to the home country are meant to fulfil a large spectrum of cognitive and emotional functions.

Figure 2: The Effect of Emotional Attachment and Regular Visits on the intention to Return

\section{Conclusions}

This article analyzed the extent to which four components of the ties established between migrants and their home country - sense of belonging, media consumption, networks of friends and regular visits - may influence the decision of migrants to return. It used 
individual-level data from a survey conducted on a convenience sample of Romanian migrants in January 2018. The findings indicate that each of these variables has a stronger effect than remittances, political participation and age. Equally important, their explanatory power differs and the strongest predictors of the desire to return are the sense of belonging (emotional attachment) and the physical presence in the country of origin (regular visits). As such, the ties with the home country appear to be established both through attitudes and behaviors. While the former can hardly be observed, the behavior, i.e. the act of visiting frequently the country of origin, is a visible predictor of their future actions. The other two behaviors tested in this article - the consumption of media and the networks of friends in the country of origin - are less influential. While the bivariate correlations show a relationship between them and return, the multivariate statistics reveals that their explanatory power is considerably less strong than that of regular visits when used in the same model.

The implications of this study reach beyond its sample of Romanian migrants. The major theoretical advancement is the identification of two variables that can be used in the study of return migration. This analysis revealed that both attitudes and behaviors shape the decision to return, with fairly similar explanatory power. As such, just by looking at one of the two separately may not explain the decision of migrants. This can contribute to the general theoretical discussion about the drivers for return, thus informing future research about the necessity to include attitudes and behaviors in the explanatory model. An empirical implication of our study is that ties with the home country are set through various means. All the determinants tested in this article have a positive and statistically significant effect on the desire to return. This observation is relevant because the level of complexity and abstraction differs across the four determinants. It ranges from very simple and concrete elements (i.e. regular visits) to more complex emotions (i.e. the attachment to the homeland). The decision to return appears to be for many migrants driven by several of these elements rather than singular causes.

These are at least two possible ways in which the findings of the current study could serve as point of departure for future analyses. To begin with, our analysis is limited to a group of first generation migrants from Romania. Further research could take this further and empirically explore these relationships for different groups of migrants. These groups can be different in terms of their experience with migration, but also have different 
countries of origin and of residence. More diverse groups of migrants could produce more robust results about the convergence or divergence of explanations. Moreover, although it reveals important patterns and trends, our study could not explore deeper the causal relationships. In this sense, a qualitative analysis could be a fruitful direction for future research. Such an avenue can take the form of interviews or focus groups with the aim to unveil how their motivation for return is formed. One useful strategy in this direction could be the selection of respondents from a few countries in which the presence of Romanian migrants is the strongest and compare their motivations to return. 
Appendix 1: Summary Statistics of the Variables Included in the Analysis

\begin{tabular}{lccccc}
\hline & Mean & Std dev & Min & Max & $\mathbf{~ N}$ \\
\cline { 2 - 6 } Intention to return & 2.21 & 2.95 & 0 & 10 & 1765 \\
Emotional attachment & 3.93 & 1.12 & 1 & 5 & 1798 \\
Media consumption & 7.36 & 3.42 & 2 & 12 & 1821 \\
Connection with friends in homeland & 3.93 & 0.99 & 1 & 5 & 1836 \\
Regular visits to Romania & 2.14 & 0.90 & 1 & 5 & 1835 \\
Remittances & 0.67 & 0.47 & 0 & 1 & 1823 \\
Voting in national elections & 2.74 & 1.68 & 1 & 5 & 1823 \\
Age & 1979 & 11 & 1937 & 1999 & 1785 \\
\hline
\end{tabular}




\section{List of references}

Anghel, R., 2013. Romanians in Western Europe: Migration, Status Dilemmas, and Transnational Connections, Lanham: Lexington Books.

Anghel, R.G., 2008. Changing Statuses: Freedom of Movement, Locality and Transnationality of Irregular Romanian Migrants in Milan. Journal of Ethnic and Migration Studies, 34(5), pp.787-802.

Atoyan, R. et al., 2016. Emigration and Its Economic Impact on Eastern Europe. IMF Staff Discussion Note, SDN/16/07. Available at: https://www.imf.org/external/pubs/ft/sdn/2016/sdn1607.pdf.

Ban, C., 2012. Economic Transnationalism and its Ambiguities: The Case of Romanian Migration to Italy. International Migration, 50(6), pp.129-149.

Barbiano di Belgiojoso, E., 2016. Intentions on desired length of stay among immigrants in Italy. Genus, 72(1), pp.1-22.

Blouchoutzi, A. \& Nikas, C., 2010. The macroeconomic implications of emigrants' remittances in Romania, Bulgaria and Albania. Post-Communist Economies, 22(4), pp.547-558.

Bolzman, C., Fibbi, R. \& Vial, M., 2006. What To Do After Retirement? Elderly Migrants and the Question of Return. Journal of Ethnic and Migration Studies, 32(8), pp.1359-1375.

Bonifazi, C. \& Paparusso, A., 2018. Remain or return home: The migration intentions of firstgeneration migrants in Italy. Population, Space and Place, online fir.

de Bree, J., Davids, T. \& de Haas, H., 2010. Post-return experiences and transnational belonging of return migrants: a Dutch-Moroccan case study. Global Networks, 10(4), pp.489-509.

Carling, J. \& Pettersen, S.V., 2014. Return Migration Intentions in the IntegrationTransnationalism Matrix. International Migration, 52(6), pp.13-30.

Cassarino, J.-P., 2004. Theorising Return Migration: A Revisited Conceptual Approach to Return Migration. EUI Working Papers, (2), pp.1-25.

Collier, W., Piracha, M. \& Randazzo, T., 2018. Remittances and return migration. Review of Development Economics, 22(1), pp.174-202.

Condon, S.A. \& Ogden, P.E., 1996. Questions of Emigration, Circulation and Return: Mobility between the French Caribbean and France. International Journal of Population Geography, 2(1), pp.35-50.

Constant, A. \& Massey, D.S., 2002. Return Migration by German Guestworkers: Neoclassical versus New Economic Theories. International Migration, 40(4), pp.5-38.

Datta, K., 2012. Migrants and their money: Surviving financial exclusion, Bristol: Policy Press.

Dustmann, C. \& Mestres, J., 2010. Remittances and Temporary Migration. Journal of Development Economics, 92(1), pp.62-70.

Duval, D.T., 2004. Linking return visits and return migration among Commonwealth Eastern Caribbean migrants in Toronto. Global Networks, 4(1), pp.51-67.

Easthope, H., 2009. Fixed Identities in a Mobile World? The Relationship Between Mobility, Place, and Identity. Identities, 16(1), pp.61-82.

Efstratios, L., Anastasios, M. \& Anastasios, K., 2014. Return migration: Evidence from a reception country with a short migration history. European Urban and Regional Studies, 21(2), pp.161-174.

Elrick, T. \& Ciobanu, O., 2009. Migration networks and policy impacts: insights from Romanian-Spanish migrations. Global Networks, 9(1), pp.100-116.

Erdal, M.B. \& Ezzati, R., 2015. 'Where are you from' or 'when did you come'? Temporal dimensions in migrants' reflections about settlement and return. Ethnic and Racial 
Studies, 38(7), pp.1202-1217.

Fargues, P., 2011. International Migration and the Demographic Transition: A Two-Way Interaction. International Migration Review, 45(3), pp.588-614.

Fehler, B.O., 2011. (Re)constructing Roots: Genetics and the 'Return' of African Americans to Ghana. Mobilities, 6(4), pp.585-600.

de Figueiredo, R.J.P. \& Elkins, Z., 2003. Are Patriots Bigots? An Inquiry into the Vices of InGroup Pride. American Journal of Political Science, 47(1), pp.171-188.

Fokkema, T., 2011. Return' Migration Intentions Among Second-Generation Turks in Europe: The Effect of Integration and Transnationalism in a Cross-National Perspective. Journal of Mediterranean Studies, 20(2), pp.365-388.

Gherghina, S. \& Tseng, H.-K., 2016. Voting home or abroad? Comparing migrants' electoral participation in countries of origin and of residence. Nationalities Papers, 44(3).

Giner-Monfort, J., Hall, K. \& Betty, C., 2016. Back to Brit: retired British migrants returning from Spain. Journal of Ethnic and Migration Studies, 42(5), pp.797-815.

Gray, B., 2008. Putting Emotion and Reflexivity to Work in Researching Migration. Sociology,, 42(5), pp.935-952.

Ha, S.E. \& Jang, S.-J., 2015. National Identity, National Pride, and Happiness: The Case of South Korea. Social Indicators Research, 121(2), pp.471-482.

de Haas, H., 2009. Euro-Mediterranean Migration Futures: The Cases of Morocco, Egypt and Turkey. Working Paper International Migration Institute.

de Haas, H. \& Fokkema, T., 2011. The effects of integration and transnational ties on international return migration intentions. Demographic Research, 25, pp.755-782.

de Haas, H., Fokkema, T. \& Fihri, M.F., 2015. Return Migration as Failure or Success? The Determinants of Return Migration Intentions among Moroccan Migrants in Europe. Journal of International Migration and Integration, 16(2), pp.415-429.

Hatziprokopiou, P. \& Labrianidis, L., 2005. Albanian Return Migration: Migrants Tend to Return to their Country of Origin After All. In R. King, N. Mai, \& S. Schwandner-Sievers, eds. The New Albanian Migration. Eastbourne: Sussex Academic Press, pp. 93-117.

Kakar, S., 1996. Colours of Violence: Cultural Identities, Religion and Conflict, Chicago: University of Chicago Press.

Kraler, A. et al. eds., 2014. Gender, Generations and Family in the International Migration, Amsterdam: Amsterdam University Press.

Labrianidis, L. \& Kazazi, B., 2006. Albanian Return-migrants from Greece and Italy. European Urban and Regional Studies, 13(1), pp.59-74.

Marcu, S., 2012. Emotions on the Move: Belonging, Sense of Place and Feelings Identities Among Young Romanian Immigrants in Spain. Journal of Youth Studies, 15(2), pp.207223.

Marcu, S., 2018. Mobility as a support strategy: Linked lives through the life course among Eastern Europeans in Spain. Geoforum, 97, pp.335-342.

Martin, R. \& Radu, D., 2012. Return Migration: The Experience of Eastern Europe ${ }^{1}$. International Migration, 50(6), pp.109-128.

McGrath, F., 1991. The Economic, Social and Cultural Impacts of Return Migration to Achill Island. In R. King, ed. Contemporary Irish Migration. Dublin: Geographical Society of Ireland, pp. 55-69.

Nedelcu, M. \& Wyss, M., 2016. 'Doing family' through ICT-mediated ordinary co-presence : transnational communication practices of Romanian migrants in Switzerland. Global Networks, 16(2), pp.202-218. 
OECD, 2017. G20 global displacement and migration trends: Report 2017. Available at: https://www.oecd.org/g20/topics/employment-and-social-policy/G20-OECDmigration.pdf.

Owusu, T.Y., 1998. To Buy or not to Buy: Determinants of Home Ownership among Ghanaian Immigrants in Toronto. The Canadian Geographer/Le Géographe canadien, 42(1), pp.40-52.

Paparusso, A. \& Ambrosetti, E., 2017. To Stay or to Return? Return Migration Intentions of Moroccans in Italy. International Migration, 55(6), pp.137-155.

Peil, M., 1995. Ghanaians Abroad. African Affairs, 94(376), pp.345-368.

Popa, D., 2018. Anul trecut au emigrat circa 220.000 de români (Last year approximately 220,000 Romanians migrated). HotNews.ro. Available at: https://economie.hotnews.ro/stiri-finante_banci-22675183-anul-trecut-emigrat-circa220-000-romni-dac-mai-sporul-natural-negativ-nu-mir-mas-19-5-milioane-trniredemografic-continu-accentueze.htm.

Repatriot, 2017. Atitudini si planuri de viitor ale romanilor din diaspora (Attitudes and Plans of Romanians in Diaspora). Report. Available at: https://repatriot.ro/wpcontent/uploads/2017/10/Prezentare-Studiu-diaspora.pdf.

Reynolds, T., 2010. Transnational family relationships, social networks and return migration among British-Caribbean young people. Ethnic and Racial Studies, 33(5), pp.797-815.

Ritchey, P.N., 1976. Explanations of Migration. Annual Review of Sociology, 2, pp.363-404.

Roman, M. \& Goschin, Z., 2014. Return Migration in an Economic Crisis Context. A Survey on Romanian Healthcare Professionals. Romanian Journal of Economics, 39(2), pp.100120.

De Rosa, D., Russo, G. \& Dospinescu, A.S., 2018. Romanian migrants can make a difference back home. The World Bank. Available at: http://blogs.worldbank.org/europeandcentralasia/romanian-migrants-can-makedifference-back-home.

Rubenstein, R., 2001. Home Matters: Longing and Belonging, Nostalgia and Mourning in Women's Fiction, New York: Palgrave Macmillan.

Sandu, D., 2009. Return Migration, as a Project and as a Mentality. In D. Sandu, ed. Romanian Communities in Spain. Bucharest: Soros Foundation Romania, pp. 43-69.

Sandu, D., 2016. Remittances as Home Orientation Rooted in the Lifeworlds of Immigrants. Central and Eastern European Migration Review, 5(2), pp.81-98.

Schatz, R.T., Staub, E. \& Lavine, H., 1999. On the Varieties of National Attachment: Blind Versus Constructive Patriotism. Political Psychology, 20(1), pp.151-174.

Smith, T.W. \& Kim, S., 2006. National Pride in Comparative Perspective: 1995/96 and 2003/04. International Journal of Public Opinion Research, 18(1), pp.127-136.

Stamm, S., 2006. Social Networks Among Return Migrants to Post-War Lebanon. CIS Working Paper, 6, pp.3-49.

Stănculescu, S. \& Stoiciu, M., 2012. Impactul crizei economice asupra migratiei fortei de munca din Romania (The Impact of Financial Crisis on the Labor Migration in Romania), Bucharest: Paideia.

Șuiu, A., 2015. Why Romanians do not Quit Spain? Romanian Migrants' Copying Strategies After the Crisis. Geographica Timisiensis, 24(2), pp.67-78.

Tsuda, T., 2003. Strangers in the ethnic homeland: Japanese Brazilian return migration in transnational perspective, New York: Columbia University Press.

Vlase, I., 2013. 'My Husband Is a Patriot!': Gender and Romanian Family Return Migration 
from Italy. Journal of Ethnic and Migration Studies, 39(5), pp.741-758.

Vlase, I. \& Voicu, B. eds., 2018. Gender, Family, and Adaptation of Migrants in Europe. A Life Course Perspective, Basingstoke: Palgrave Macmillan.

Waddell, B.J. \& Fontenla, M., 2015. The Mexican Dream? The effect of return migrants on hometown development. The Social Science Journal, 52(3), pp.386-396.

Waldorf, B., 1995. Determinants of International Return Migration Intentions*. The Professional Geographer, 47(2), pp.125-136.

Wessendorf, S., 2007. 'Roots Migrants': Transnationalism and 'Return' among SecondGeneration Italians in Switzerland. Journal of Ethnic and Migration Studies, 33(7), pp.1083-1102.

Zaiceva, A. \& Zimmermann, K.F., 2012. Returning Home at Times of Trouble? Return Migration of EU Enlargement Migrants during the Crisis. IZA DP, 7111. Available at: https://pdfs.semanticscholar.org/374f/86f3e8e6aee36a84c318c991c1cea66497ab.pdf.

Zaiceva, A. \& Zimmermann, K.F., 2008. Scale, diversity, and determinants of labour migration in Europe. Oxford Review of Economic Policy, 24(3), pp.427-451.

Zhao, Y., 2002. Causes and Consequences of Return Migration: Recent Evidence from China. Journal of Comparative Economics, 30(2), pp.376-394. 